\title{
STRATEGIC QUALITY PLANNING DALAM MEMBANGUN MADRASAH UNGGUL
}

\author{
Oleh: \\ Fahliyatun Nisa' ${ }^{1} \&$ Makhsushoh Turrif'ah ${ }^{2}$ \\ Email : faly74li10@yahoo.com \\ Email: makhsushoh@gmail.com
}

\begin{abstract}
This article is reflective writing in managing and developing madrasah. The study is based on experience and analysis of various sources and expectations for building exellent Islamic Schools (madrasah). Some steps in strategic quality planning in an effort to build exellent madrasah are conceptualized into 7 steps : 1). Formulate the vision, mission, values, goals and exellent programs with consideration not to get out of the corridor of national education goals and the peculiarities of the madrasah; 2). Analyze the madrasa market by considering location, needs, and carrying capacity; 3). The need for a SWOT analysis that can be divided into internal and external analysis and important success factors contained in the vision and mission statement, 4). Shortterm detailed planning through the Annual Work Plan, 5). Following the standard determined; 6). Quality costs related to the creation, identification, repair and removal of damage; and 7). supervision and evaluation to what extent the institution is able to achieve its mission and strategic goals.
\end{abstract}

\begin{abstract}
Abstrak
Tulisan ini merupakan refleksi penulis dalam mengelola dan mengembangkan madrasah. Kajian didasarkan pada pengalaman dan analisis berbagai sumber serta harapan-harapan untuk membangun madrasah unggul. Beberapa langkah dalam strategic quality planning dalam upaya membangun madrasah unggul terkonsepkan kedalam 7 langkah, yaitu: 1). Merumuskan visi, misi, nilai-nilai, tujuan dan program unggulan dengan pertimbangan tidak keluar dari koridor tujuan pendidikan Nasional serta kekhasan madrasah; 2). Analisa pasar madrasah dengan mempertimbangkan lokasi, kebutuhan, dan daya dukung; 3). Perlunya analisa SWOT yang dapat dibagi ke dalam analisa internal dan eksternal serta faktor penting sukses yang tertuang dalam statemen visi dan misinya, 4). Perencanaan detail jangka pendek melalui Rencana Kerja Tahunan, 5). Mengikuti standar yang ditetapkan; 6). Biaya mutu terkait dengan penciptaan, pengidentifikasian, perbaikan dan pencagahan kerusakan; serta 7). pengawasan dan evaluasi sejauh mana institusi mampu mencapai misi dan tujuan strategisnya.
\end{abstract}

Kata Kunci: 7 Langkah Strategik, Quality Planning, Madrasah Unggul

\footnotetext{
${ }^{1}$ Kepala Madrasah Tsanawiyah Bahrul Ulum Tajinan - Kab. Malang

2 Wakil Kepala Bidang Kesiswaan di Madrasah Tsanawiyah Bahrul Ulum -Tajinan Kab. Malang
} 


\section{A. Pendahuluan}

Beberapa tahun terakhir ini perkembangan dunia pendidikan sangatlah cepat dan membuat pihak-pihak yang terlibat didalamnya harus bekerja keras agar keberadaannya tetap diakui oleh pelanggan mereka. Bervariasinya "merk" dan "jenis produk" menunjukkan bahwa institusi tidak dapat hanya berdiam diri dalam melakukan "bisnis"nya. Mereka harus mulai berpikir untuk mengalahkan pesaingnya. ${ }^{3}$

Kualitas dari sebuah lembaga pendidikan saat ini tidak hanya dilihat dari desain produk dan proses yang berorientasi pada kebutuhan penikmat pendidikan, namun kualitas yang tak kalah penting adalah kualitas pelayanan yang diberikan lembaga pendidikan tersebut kepada para pelanggan setianya, yang membuat mereka tetap bertahan dengan produk yang telah dihasilkan oleh lembaga tersebut.

Bagi setiap institusi, mutu adalah agenda utama dan meningkatkan mutu merupakan tugas yang paling penting. Mutu dalam pendidikan merupakan hal yang membedakan antara kesuksesan dan kegagalan. Sehingga, mutu merupakan masalah pokok yang akan menjamin perkembangan sekolah dalam meraih status di tengah-tengah persaingan dunia pendidikan yang kian keras. ${ }^{4}$

Pengetahuan luas saja tidak bisa menjamin seorang lulusan dapat bicara banyak dalam persaingan global. Diperlukan pula keahlian spesifik yang selaras dengan kebutuhan lapangan. Jika tidak demikian, maka lulusan pendidikan akan terlindas dan tersingkirkan. Lebih-lebih saat ini dunia telah memasuki era baru, yakni Era Revolusi Industri 4.0. Era Revolusi Industri 4.0 (selanjutnya: Era 4.0) membawa dampak yang tidak sederhana. Ia berdampak pada seluruh aspek kehidupan manusia termasuk pendidikan. Era ini ditandai dengan semakin sentralnya peran teknologi cyber dalam kehidupan manusia. Maka tak heran jika dalam dunia pendidikan muncul istilah "Pendidikan 4.0". Pendidikan 4.0 (Education 4.0) adalah istilah umum digunakan oleh para ahli pendidikan untuk menggambarkan berbagai cara untuk mngintegrasikan teknologi cyber baik secara fisik maupun tidak ke dalam pembelajaran. Munculnya revolusi industri keempat dimana manusia dan mesin diselaraskan untuk mendapatkan solusi, memecahkan masalah dan tentu saja menemukan kemungkinan inovasi baru.

Keberhasilan penyelenggaraan pendidikan di lembaga pendidikan hakekatnya tidak terlepas dari setiap jaringan kerja yang berjalan sesuai rencana strategik dan tujuan yang telah ditetapkan sebelumnya secara efektif dan efisien. Jaringan-jaringan kerja seperti manajemen madrasah,

\footnotetext{
${ }^{3}$ Agustinus Sri Wahyudi, Manajemen Strategik, Pengantar Proses Berpikir Strategik (Binarupa Aksara, 1996), Hlm. 3

${ }^{4}$ Edward Sallis, Manajemen Mutu Terpadu Pendidikan (Jogjakarta: Ircisod, 2011), Hlm. 29-30
} 
kinerja karyawan dan lain sebagainya merupakan komponen penting untuk mewujudkan mutu pendidikan. Sehingga dapat dikatakan tanpa suatu perencanaan, organisasi itu akan mengalami kegagalan dalam pencapaian apa yang diharapkan.

Pendidikan yang terencana adalah pendidikan yang diselenggarakan melalui proses perencanaan yang matang. Perencanaan merupakan tindakan awal dalam proses manajemen. Perencanaan strategik sebagai suatu konsep yang terkait dengan faktor waktu melibatkan suatu proses yang kontinu dan interaktif dalam mencapai tujuan organisasi yang sesuai dengan kondisi lingkungan yang dihadapinya. Oleh karena itu, rencana strategik dapat digunakan untuk mengidentifikasi kegiatan yang menjanjikan berfokus pada sumber daya (alam, manusia dan buatan) untuk pengembangan jangka panjang serta menguntungkan. ${ }^{5}$

Atas dasar hal diatas, Madrasah dengan berbagai potensi dan tantangan yang dihadapi mulai berbenah khususnya dalam penataan ulang orintasi lembaga menuju lembaga yang unggul dimuai dari tahap perencanaan strategisnya. Dan inilah yang menjadi fokus dari tulisan ini.

\section{B. Pembahasan}

\section{Perencanaan Strategik: Makna dan Formulasinya}

Sebelum mengkaji tentang perencanaan strategik, penting untuk terlebih dahulu dikaji mengenai arti strategi. Menurut Adkon, perkataan "Strategik" diawali dan popular di lingkungan militer. Dilingkungan tersebut penggunaannya lebih dominan dalam situasi peperangan, sebagai tugas seorang komandan dalam menghadapi musuh, yang bertanggung jawab mengatur cara atau taktik untuk memenangkan peperangan. Oleh karena itu, jika keliru dalam memilih dan mengatur cara dan taktik sebagai strategi peperangan, maka nyawa prajurit akan menjadi taruhannya. Dengan demikian, yang dimaksud dengan strategi dalam peperangan adalah pengaturan cara untuk memenangkan peperangan. ${ }^{6}$ Juga dapat dimaknai sebagai rancangan yang bersifat sistematik itu, di lingkungan sebuah organisasi disebut "Perencanaan Strategik".7 Strategi memiliki konsekuensi yang multifungsi dan multidimensi serta perlu mempertimbangkan faktorfaktor eksternal dan internal yang di hadapi perusahaan/organisasi. ${ }^{8}$

\footnotetext{
${ }^{5}$ Musa Hubeis dan Muhamad Najib, Manajemen Strategik dalam Pengembangan Daya Saing dan Organisasi (Jakarta: PT Elex Media Komputindo, 2008), HIm. 5

${ }^{6}$ Akdon, Strategic Management For Educational Management (Bandung: Alfabeta, 2009), Hlm. 3

${ }^{7}$ Hadari Nawawi, Manajemen Strategik Organisasi Non Profit Bidang Pemerintahan (Yogyakarta: Gadjah Mada University Press, 2005), Hlm. 147

8 Fred R David, Manajemen Strategis, Edisi 10 (Jakarta: Salemba Empat, 2006), Hlm. 16-17
} 
Dari pengertian strategi tersebut dapat disimpulkan bahwa strategi pada dasarnya adalah sebuah perencanaan yang bersifat besar, luas dan terintegrasi serta berorientasi masa depan sehingga sangat berpengaruh bagi kemajuan organisasi, dengan mempertimbangkan faktor-faktor eksternal dan internal untuk meraih tujuan organisasi.

Sedangkan perencanaan merupakan kegiatan yang dilakukan oleh pimpinan organisasi untuk memilih cara dan penggunaan sumber daya organisasi yang tepat dalam mencapai tujuannya sebagaimana pandangan Wilson Bangun perencanaan adalah suatu rangkaian kegiatan dalam pengambilan keputusan (decision making), dalam menentukan sasaran, metode, waktu dan orang yang tepat yang dilakukan manajer dalam suatu organisasi. ${ }^{9}$ Tanpa rencana, manajer tidak mungkin dapat mengorganisasikan dan menggerakkan sumber daya yang digunakan secara tepat. Karena itu, perencanaan akan menentukan adanya perbedaan kinerja (performance) satu organisasi dengan organisasi lain dalam pelaksanaan rencana untuk mencapai tujuan. ${ }^{10}$

Perencanaan dapat diartikan sebagai proses penyusunan berbagai keputusan yang akan dilaksanakan pada masa yang akan datang untuk mencapai tujuan yang telah ditentukan. Perencanaan itu dapat pula di beri arti sebagai suatu proses pembuatan serangkaian kebijakan untuk mengendalikan masa depan sesuai yang ditentukan. ${ }^{11}$ Perencanaan strategik pada dasarnya untuk menjawab satu pertanyaan pokok, "Apa yang akan diperbuat." Perencanaan strategik adalah instrumen kepemimpinan dan suatu proses. Sebagai suatu proses, ia menentukan apa yang dikehendaki suatu organisasi masa depan dan bagaimana usaha mencapainya, "suatu proses yang menjelaskan sasaran-sasaran". ${ }^{12}$ Menurut Husein Umar, perencanaan strategik (strategic planning) merupakan bagian dari manajemen strategik. ${ }^{13}$

Perencanaan strategik sebagai proses dinamik yang harus dapat menggerakkan seluruh bagian organisasi. Organisasi dapat melakukan rencana strategik apabila:

a. Dapat menggambarkan masa depannya secara jelas

b. Dapat merumuskan atau menyimpulkan misinya

\footnotetext{
9 Wilson Bangun, Intisari Manajemen (Bandung: PT Refika Aditama, 2008), Hlm. 75

10 Syafaruddin, Manajemen Lembaga Pendidikan Islam (Jakarta: PT Ciputat Press, 2005), Hlm. 61

${ }^{11}$ Udin Syaefudin Sa'ud dan Abin Syamsuddin Makmun, Perencanaan Pendidikan: Suatu Pendekatan Komprehensif (Bandung: Remaja Rosdakarya, 2007), Hlm. 4-5

12 J. Salusu, Pengambilan Keputusan Strategik Untuk Organisasi Publik dan Organisasi Non Profit (Jakarta: Grasindo, 2006), Hlm. 500

${ }^{13}$ Husein Umar, Strategic Management in Action (Jakarta: PT Gramedia Pustaka Utama, 2005), Hlm. 17
} 
c. Dapat membedakan misinya dengan misi organisasi diatasnya

d. Dapat mengetahui "customers" nya yang penting

e. Terdapat pimpinan yang menghayati perlunya kualitas dan produktivitas $^{14}$

\section{Perencanaan Strategis Mutu di Madrasah}

Dalam era industrialisasi yang semakin kompetitif sekarang ini, setiap pelaku bisnis yang ingin memenangkan kompetisi dalam dunia industri akan memberikan perhatian penuh kepada mutu/kualitas. Mutu harus menjadi bagian penting dari strategi institusi, dan harus didekati secara sistematis dengan menggunakan proses perencanaan strategis. Perencanaan strategis merupakan salah satu bagian terpenting karena tanpa arahan jangka panjang yang jelas, sebuah institusi tidak dapat merencanakan peningkatan mutu. ${ }^{15}$

Perencanaan strategis mutu ialah perencanaan berjangka panjang berdasarkan visi, misi dan prinsip kelembagaan, yang berorientasi pada kebutuhan para pelanggan baik masa kini maupun masa yang akan datang.

Dr. Joseph M Juran, salah seorang guru dalam manajement sebagaimana yang dikutip Vincent Gaspersz menjelaskan bahwa pendekatannya terhadap perencanaan mutu (quality planning) melibatkan beberapa aktivitas berikut: 1). Identifikasi pelanggan. Setiap orang yang akan dipengaruhi adalah pelanggan; 2). Menentukan kebutuhan pelanggan; 3). Menciptakan keistimewaan produk yang dapat memenuhi kebutuhan pelanggan; 4). Menciptakan proses yang mampu menghasilkan keistimewaan produk di bawah kondisi operasi; dan 5). Mentransfer/mengalihkan proses ke operasi. Dalam pandangan gaspresz, perencanaan mutu/kualitas seharusnya melibatkan partisipasi mereka yang akan dipengaruhi oleh rencana. Juga mereka yang merencanakan kualitas seharusnya dilatih dalam menggunakan metode-metode modern dan alat-alat perencanaan kualitas. ${ }^{16}$

Dalam konteks madrasah, perencanaan strategis mutu tercermin dalam perencanaan yang terprogram dan terarah. Perencanaan meliputi rencana jangka menengah dan pendek. Hal ini diperkuat dengan diterbitkannya Permendiknas Nomor 19 Tahun 2007 tentang Standar Pengelolaan yang menyatakan bahwa sekolah harus membuat Rencana Kerja Sekolah yang terdiri dari Rencana Kerja Jangka Menengah (RKJM) dan Rencana Kerja Tahunan (RKT). RKJM menggambarkan tujuan yang akan dicapai dalam kurun waktu empat

\footnotetext{
${ }^{14}$ Soewarso Hardjosoedarmo, Total Quality Management (Yogyakarta: ANDI, 2004), Hlm. 76

15 Sallis, Manajemen..., Hlm. 211

16 Vincent Gaspersz, Total Quality Management (Jakarta: Gramedia Pustaka Utama, 2001), 7-8
} 
tahun, sedangkan Rencana Kerja Tahunan (RKT) dicapai dalam kurun waktu satu tahunan. Permendiknas tersebut juga menyatakan bahwa RKT adalah rencana kerja tahunan madrasah yang berdasar pada rencana kerja jangka menengah yang dinyatakan dalam Rencana Kegiatan dan Anggaran Madrasah (RKAM) sebagai istilah lain dari Rencana Anggaran Penerimaan dan Belanja Madrasah (RAPBM).

Peraturan lain yang mendukung perencanaan program sekolah ini adalah Peraturan Pemerintah Nomor 17 Tahun 2010 tentang Pengelolaan dan Penyelenggaraan Pendidikan pasal 51 menyatakan, bahwa satuan pendidikan harus membuat kebijakan tentang perencanaan program dan pelaksanaannya secara transparan dan akuntabel. Kebijakan pendidikan sebagaimana dimaksud pada pasal 51, oleh satuan pendidikan dituangkan dalam: 1). rencana kerja tahunan satuan pendidikan; 2). anggaran pendapatan dan belanja tahunan satuan pendidikan; dan 3). Peraturan satuan atau program pendidikan.

\section{Manfaat Perencanaan Strategik dalam Membangun Mutu dan Produktivitas}

Proses perencanaan strategis dalam konteks pendidikan tidak jauh berbeda dengan yang biasanya dipergunakan dalam dunia industri dan komersial. Alat-alat yang digunakan dalam langkah-langkah perencanaan strategis juga hampir sama, hanya perlu penerjemahan yang baik. ${ }^{17}$ Apabila dilaksanakan dengan benar dan didukung oleh komitmen pimpinan, perencanaan strategik dapat memberi manfaat bagi organisasi, sebagai berikut:

a. Perencanaan strategik dapat memperkuat "critical mass" 18 menjadi team yang kompak, karena diarahkan untuk menganut nilai-nilai pokok, sistem utama dan tujuan bersama;

b. Perencanaan strategik dapat membantu untuk mengoptimisasikan "performance" organisasi;

c. Perencanaan strategik membantu pimpinan untuk selalu memusatkan perhatian dan menganut kerangka bagi upaya perbaikan secara kontinu.

d. Perencanaan strategi memberikan pedoman bagi pengambilan keputusan sehari-hari.

e. Perencanaan strategik selalu memberikan kemudahan untuk mengukur kemajuan organisasi dalam usaha mencapai tujuannya untuk memperbaiki kualitas dan produktivitas madrasah. ${ }^{19}$

\footnotetext{
${ }^{17}$ Sallis, Manajemen..., Hlm. 212

${ }^{18}$ Critical mass adalah kelompok tenaga inti suatu organisasi yang memiliki motivasi, aptidute dan pengetahuan mendasar untuk meningkatkan kualitas produk-produk organisasi ${ }^{19}$ Hardjosoedarmo, Total Quality ..., 76
} 
Upaya peningkatan mutu memang tidak dapat dipisahkan dari usaha peningkatan produktivitas. Usaha yang berlebihan untuk mendorong produktivitas dapat mengorbankan mutu dari output. Sebaliknya, fokus yang berlebihan pada peningkatan mutu dapat mengurangi perhatian untuk memperbaiki produktivitas, bahkan mungkin akan mengorbankan produktivitas demi mengejar mutu yang tinggi. Jadi, keduanya saling berhubungan dan saling melengkapi satu sama lain. ${ }^{20}$

Deming (Hardjosoedarmo) melakukan pengkajian tentang bagaimana melakukan perbaikan secara berkelanjutan dan mencapai hasil gemilang dalam organisasi. Dalam pengkajian tersebut, Deming memandang kualitas dengan cara baru. Premis pandangan baru Deming terhadap kualitas tersebut di rumuskan sebagai "Reaksi Berantai Deming untuk memperbaiki kualitas". Premis tersebut menyatakan: "Dengan memperbaiki kualitas, biaya akan menurun dan produktivitas meningkat." Premis Deming tersebut mempunyai implikasi bahwa dengan biaya yang semakin rendah dan kualitas semakin tinggi, maka organisasi mempunyai potensi untuk meningkatkan market share dan pertumbuhannya. ${ }^{21}$

Menghayati reaksi berantai Deming ini penting, karena model ini memang merupakan pandangan baru mengenai hubungan antara kualitas, biaya dan produktivitas. Dahulu banyak organisasi yang berusaha meningkatkan produktivitasnya, namun membiarkan kualitasnya konstan. Reaksi berantai menyatakan bahwa turunnya biaya dan meningkatnya produktivitas adalah akibat meningkatnya kualitas.

Dengan "reaksi berantai Deming" tersebut, maka timbul pertanyaan, manakah yang harus didahulukan antara kualitas atau produktivitas dalam melakukan perencanaan strategik? Dari persoalan tersebut, bukanlah mana yang terdahulu, melainkan siapa yang harus didahulukan. maka kebutuhan kustomerlah yang harus didahulukan, yang berarti kualitas daripada produktivitas. ${ }^{22}$ berikut adalah gambar reaksi berantai Deming:

20 Nasutioan, Manajemen Mutu Terpadu (Total Quality Management) (Jakarta: Ghalia Indonesia, 2001), 216

${ }^{21}$ Hardjosoedarmo, Total Quality ..., Hlm, 87

22 Hardjosoedarmo, Total Quality ..., Hlm. 88 


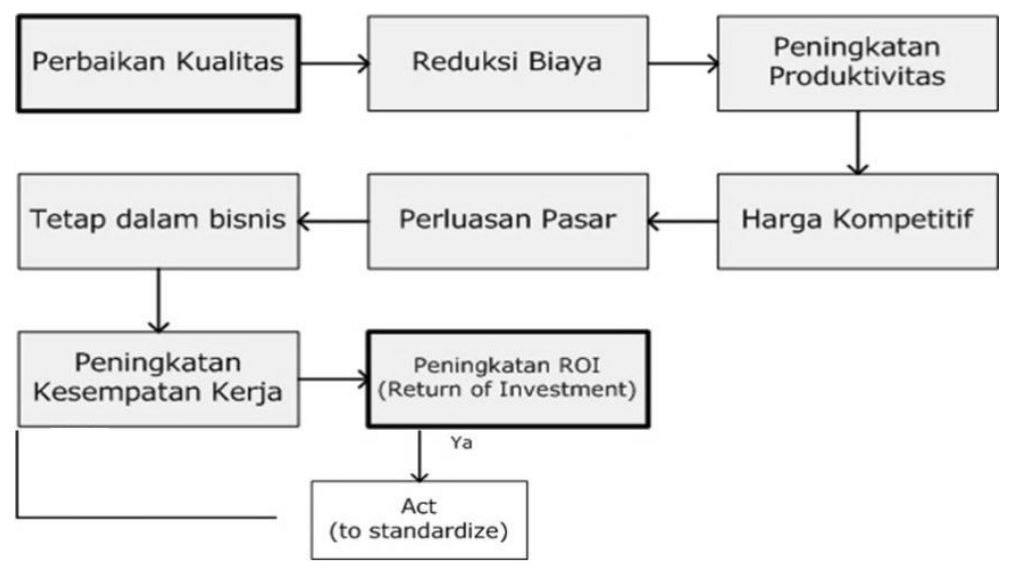

Gambar 1: Reaksi Berantai Deming untuk memperbaiki kualitas

Menurut Deming, terdapat lima hal yang harus diwaspadai dalam konteks pendidikan khususnya di madrasah, yaitu: (1). Kurang konstannya tujuan; (2). Pola pikir jangka pendek; (3). Evaluasi prestasi individu; (4). Rotasi kerja yang tinggi. Dan (5). Manajemen yang menggunakan angka yang tampak.

Kegagalan mutu terbagi dalam dua bagian, yaitu : secara umum terdiri dari: desain kurikulum yang lemah, bangunan yang tidak memenuhi syarat, lingkungan kerja yang buruk, sistem dan prosedur yang tidak sesuai, jadwal kerja yang serampangan, sumberdaya yang kurang, dan pengembangan staf yang tidak memadai. Dan secara khusus kurangnya pengetahuan dan keterampilan anggota, kurangnya motivasi, kegagalan komunikasi, atau masalah yang berkaitan dengan perlengkapan-perlengkapan.

\section{Langkah-langkah Perencanaan Strategis Mutu dalam Membangun Madrasah Unggul: Sebuah Refleksi}

Perencanaan strategis tidak mempunyai langkah-langkah dan rangkaian aktivitas yang khusus dalam mengupayakannya. Meskipun demikian, menggunakan sebuah pendekatan yang sistematis dalam merencanakan masa depan institusi merupakan hal yang penting. Strategi harus didasarkan pada kelompok-kelompok pelanggan dan harapanharapan mereka yang bervariasi, dan mengembangkan kebijakan-kebijakan serta rencana-rencana yang dapat mengantarkan pada pencapaian misi dan visinya. 23

Edward Sallis menjelaskan sebuah rangkaian perencanaan strategis yang bisa diadopsi oleh beberapa institusi pendikan, sebagai berikut: ${ }^{24}$

23 Sallis, Manajemen Mutu ..., Hlm. 214

${ }^{24}$ Sallis, Manajemen Mutu ..., Hlm . 215 
JURNAL PIWULANG, Vol. I No. 2 Maret 2019, 137-155

\begin{tabular}{|c|l|l|} 
a & Visi, Misi, dan Tujuan & Apa jenis usaha kita? \\
\hline b & Analisa Pasar & $\begin{array}{l}\text { Siapa pelanggan kita dan apa } \\
\text { yang mereka harapkan? }\end{array}$ \\
\hline c & $\begin{array}{l}\text { Analis SWOT dan Faktor } \\
\text { Penting Sukses }\end{array}$ & $\begin{array}{l}\text { Apa yang kita butuhkan agar } \\
\text { menjadi baik? }\end{array}$ \\
\hline d & $\begin{array}{l}\text { Perencanaan Operasi dan } \\
\text { Bisnis }\end{array}$ & $\begin{array}{l}\text { Bagaimana cara agar kita meraih } \\
\text { kesuksesan? }\end{array}$ \\
\hline e & $\begin{array}{l}\text { Kebijakan dan Perencanaan } \\
\text { Mutu }\end{array}$ & $\begin{array}{l}\text { Bagaimana cara kita berbuat dalam } \\
\text { menyampaikan mutu? }\end{array}$ \\
\hline 6 & Biaya Mutu & Biaya apa yang dibutuhkan mutu? \\
\hline 7 & Monitoring dan Evaluasi & $\begin{array}{l}\text { Bagaimana kita tahu bahwa kita } \\
\text { sukses? }\end{array}$ \\
\hline
\end{tabular}

a. Merumuskan Visi, Misi, Nilai-nilai dan Tujuan

Sebagian besar organisasi membedakan visi, misi, nilai-nilai dan tujuan mereka dengan maksud untuk memperjelas jenis institusi seperti yang mereka harapkan nantinya dan memperjelas arah mana yang mereka tuju.

1) Statemen visi mengisyaratkan tujuan puncak dari sebuah institusi dan untuk apa visi itu dicapai. Visi harus singkat, langsung dan menunjukkan tujuan puncak institusi. Misalnya, "Terwujudnya Madrasah yang Unggul dan Rujukan dalam Pendidikan guna menghasilkan Lulusan yang memiliki Kecerdasan, Akhlaqul Karimah dan Berwawasan Nusantara".

Visi adalah pernyataan yang diucapkan atau ditulis hari ini, yang merupakan proses manajemen saat ini yang menjangkau masa yang akan datang. ${ }^{25}$ Visi adalah wawasan yang menjadi sumber arahan bagi madrasah dan digunkan untuk memandu perumusan misi madrasah. Dengan kata lain, visi adalah pandangan jauh ke depan kemana madrasah akan dibawa. Visi adalah gambaran masa depan yang diinginkan oleh madrasah agar menjamin keberlangsungan hidupnya.

Menurut Akdon (2006:96), terdapaat beberapa kriteri dalam merumuskan visi, antara lain: ${ }^{26} 1$ ) Visi bukanlah fakta, tetapi gambaran pandangan ideal masa depan yang ingin diwujudkan; 2) Visi dapat memberikan arahan, mendorong anggota organisasi untuk menunjukkan kinerja yang baik; 3) Dapat menimbulkan inspirasi dan siap menghadapi tantangan; 4) Menjembatani masa kini dan masa yang akan dating; 5)

${ }^{25}$ Akdon, Strategic Managemen for Educational Management. (Bandung: Alfabeta, 2006). Hlm, 94

${ }^{26}$ Akdon, Strategic Managemen ... Hlm. 86

- Fahliyatun Nisa' \& Makhsushoh Turrifah- 145 
Gambaran yang realistik dan kredibel dengan masa depan yang menarik. Dan 6) Sifatnya tidak statis dan tidak untuk selamanya.

Gambaran visi madrasah tentu harus didasarkan pada landasan yuridis, disamping nilai-nilai yang dianut oleh lembaga tersebut. Dengan kata lain, visi madrasah harus tetap dalam koridor kebijakan pendidikan Nasional, namun tetap sesuai dengan nilai-nilai dan kebutuhan anak didik dan masyarakat yang dilayaninya. Oleh karena itu, dimungkinkan madrasah memiliki visi yang tidak sama dengan madrasah lainnya, tetapi tetap dalam koridor tujuan pendidikan Nasional.

2) Statemen misi sangat berkaitan dengan visi dan memberikan arahan yang jelas baik untuk masa sekarang maupun untuk masa yang akan datang. Statemen misi membuat visi memperjelas alasan kenapa sebuah institusi berbeda dari institusi-institusi yang lain. Misalnya, Hightown School bertujuan untuk memberikan mutu pendidikan yang terbaik kepada para pelajarnya.

Misi adalah pernyataan mengenai hal-hal yang harus dicapai organisasi bagi pihak-pihak yang berkepentingan di masa datang Pernyataan misi mencerminkan tentang penjelasan produk atau pelayanan yang ditawarkan. Pernyataan misi harus: (1). Menunjukkan secara jelas mengenai apa yang hendak dicapai oleh organisasi dan bidang kegiatan utama dari organisasi yang bersangkutan. (2). Secara eksplisit mengandung apa yang harus dilakukan untuk mencapainya. Dan (3). Mengundang partisipasi masyarakat luas terhadap perkembangan bidang utama yang digeluti organisasi.27

Diantara contoh rumusan misi madrasah adalah sebagai berikut: (1). Menyelengarakan pembelajaran dalam mengembangkan multiple intelligences anak didik. (2). Menyelenggarakan pembelajaran internalisasi nilai-nilai cinta ilmu pengetahuan, teknologi dan seni; (3). Menyelengarakan pembelajaran dalam mengembangkan akhlakul karimah anak didik; (4). Menyelenggarakan pembelajaran internalisasi nilainilai cinta Allah, Sesama dan Alam semesta; (5). Menyelengarakan pembelajaran dalam mengembangkan wawasan nusantara anak didik; dan (6). Menyelenggarakan

${ }^{27}$ Akdon, Strategic Managemen ... Hlm. 97-98 
pembelajaran internalisasi nilai-nilai cinta diri, bangsa dan Negara

Beberapa hal yang harus diperhatikan dalam merumuskan misi sekolah antara lain: 1). Pernyataan misi sekolah harus menunjukkan secara jelas mengenai apa yang hendak dicapai oleh madrasah. 2). Rumusan misi madrasah selalu dalam bentuk kalimat yang menunjukkan "tindakan" dan bukan kalimat yang menunjukkan "keadaan" sebagaimana pada rumusan visi. 3). Satu indikator visi dapat dirumuskan lebih dari satu rumusan misi. Antara indikator visi dengan rumusan misi harus ada keterkaitan atau terdapat benang merahnya secara jelas. 4). Misi madrasah menggambarkan tentang produk atau pelayanan yang akan diberikan pada masyarakat (siswa) dan 5). Kualitas produk atau layanan yang ditawarkan harus memiliki daya saing yang tinggi, namun disesuaikan dengan kondisi madrasah.

3) Nilai-nilai dari sebuah organisasi merupakan prinsip-prinsip yang menjadi dasar operasi dan pencarian organisasi tersebut dalam mencapai visi dan misinya. Nilai-nilai tersebut mengekspresikan kepercayaan dan cita-cita institusi. Nilai-nilai yang ada dalam institusi harus disesuaikan dengan lingkungan dimana institusi tersebut beroperasi dan menancapkan hubungan kuat baik dengan pelanggan maupun dengan para staf. Setidak-tidaknya mencakup beberapa hal berikut ini: peserta didik sebagai fokusnya, bekerja dengan standar integritas profesional tertinggi, bekerja sebagai tim, memiliki komitmen terhadap peningkatan yang kontinyu, memberi kesempatan yang sama pada semua, dan memberikan mutu pelayanan tertinggi.

4) Setelah visi, misi, dan nilai-nilai telah ditetapkan. Ketiganya harus diterjemahkan ke dalam tujuan-tujuan yang bisa dicapai. Tujuan sering diekspresikan sebagai sasaran dan cita-cita. Sebuah tujuan harus diekspresikan dalam metode yang terukur sehingga hasil akhirnya dapat dievaluasi dengan menggunakan metode tersebut.

Tujuan merupakan penjabaran dari pernyataan misi, tujuan adalah sesuatu yang akan dicapai atau dihasilkan dalam jangka waktu yang telah ditentukan. Tujuan tidak harus dinyatakan dalam bentuk kuantitatif, akan tetapi harus dapat 
menunjukkan kondisi yang ingin dicapai di masa mendatang.28 Tujuan akan mengarahkan perumusan sasaran, kebijaksanaan, program dan kegiatan dalam rangka merealisasikan misi, oleh karena itu tujuan harus dapat menyediakan dasar yang kuat untuk menetapkan indikator.

Oleh karena itu perumusan tujuan harus memberikan ukuran lebih spesifik dan akuntabel. Beberapa hal yang harus diperhatikan dalam merumuskan tujuan madrasah, antara lain: 1) Tujuan madrasah harus memberikan ukuran yang spesifik dan akuntabel (dapat diukur); 2) Tujuan madrasah merupakan penjabaran dari misi, oleh karena itu tujuan harus selaras dengan visi dan misi; 3) Tujuan sekolah menyatakan kegiatan khusus apa yang akan diselesaikan dan kapan diselesaikannya.

5) Program Unggulan. Program merupakan implementasi dari visi, misi dan tujuan. Program yang dimaksudkan dalam makalah ini adalah program unggulan madrasah yang dapat dilaksanakan secara operasional. Program operasional didefinisikan sebagai kumpulan kegiatan yang dihimpun dalam satu kelompok yang sama secara sendiri-sendiri atau bersama-sama untuk mencapai tujuan dan sasaran.29 Program unggulan merupakan kumpulan kegiatan nyata, sistematis dan terpadu, dilaksanakan oleh satu instansi atau lebih ataupun dalam rangka kerja sama dengan masyarakat atau yang merupakan partisipasi aktif masyarakat guna mencapai tujuan dan sasaran yang telah ditetapkan.

Wujud nyata sebuah organisasi adalah adanya program unggulan operasional yang akan dilaksanakan dalam bentuk kegiatan. Beberapa ciri-ciri program operasional adalah: 1) Program kerja operasional didasarkan atas perumusan visi, misi, tujuan, sasaran dan kebijakan yang telah ditetapkan; 2) Program kerja operasional pada dasarnya merupakan upaya untuk implementasi strategi organisasi; 3) Program kerja operasional merupakan proses penentuan jumlah dan jenis sumber daya yang diperlukan dalam rangka pelaksanaan satu rencana; 4) Program operasional merupakan penjabaran riil tentang langkah-langkah yang diambil untuk menjabarkan kebijakan; 5) Program operasional dapat bersifat jangka panjang dan menengah, atau bersifat tahunan; 6) Program kerja operasional tidak terlepas dari kebijakan yang telah ditetapkan sebelumnya.

${ }^{28}$ Akdon, Strategic Managemen ... Hlm. 143

${ }^{29}$ Akdon, Strategic Managemen ... Hlm. 135 
Berikut adalah contoh rumusan visi, misi, tujuan madrasah serta program unggulan sebagaimana dalam tabel berikut:

\begin{tabular}{|c|c|c|c|c|}
\hline VISI & MISI & & TUJUAN & $\begin{array}{l}\text { PROGRAM } \\
\text { UNGGULAN }\end{array}$ \\
\hline \multirow[t]{4}{*}{$\begin{array}{l}\text { Terwujudnya } \\
\text { Madrasah } \\
\text { Aiyah yang } \\
\text { Unggul dan } \\
\text { Rujukan dalam } \\
\text { Pendidikan } \\
\text { guna } \\
\text { menghasilkan } \\
\text { Lulusan yang } \\
\text { memiliki } \\
\text { Kecerdasan, } \\
\text { Akhlaqul } \\
\text { Karimah dan } \\
\text { Berwawasan } \\
\text { Nusantara }\end{array}$} & \multirow[t]{2}{*}{$\begin{array}{l}\text { 1. Menyelengara } \\
\text { kan } \\
\text { pembelajaran } \\
\text { dalam } \\
\text { mengembangk } \\
\text { an multiple } \\
\text { intelligences } \\
\text { anak didik. }\end{array}$} & \multicolumn{2}{|c|}{$\begin{array}{ll}\text { 1.1 } & \text { Menghasilkan } \\
\text { lulusan yang } \\
\text { memiliki multiple } \\
\text { intelligences dan } \\
\text { kecakapan berpikir } \\
\text { kritis, kreatif, } \\
\text { kolaboratif, dan } \\
\text { komunikatif dalam } \\
\text { memecahkan } \\
\text { masalah melalui } \\
\text { kegiatan akademik } \\
\text { dan non akademik. }\end{array}$} & \multirow{4}{*}{$\begin{array}{l}\text { 1. We Love } \\
\text { Qur'an. } \\
\text { 2. Klinik } \\
\text { Ubudiyah. } \\
\text { 3. Grow with } \\
\text { Character. } \\
\text { 4. We Are } \\
\text { Champions } \\
\text { 5. SEHATI } \\
\text { (sejuk, } \\
\text { sehat dan } \\
\text { indah) } \\
\text { 6. Speaking } \\
\text { Practice. } \\
\text { 7. Pendidikan } \\
\text { Wawasan } \\
\text { Nusantara. } \\
\text { 8. Edupreneu } \\
\text { rship }\end{array}$} \\
\hline & & 1.2 & $\begin{array}{l}\text { Menyiapkan anak } \\
\text { didik yang terampil } \\
\text { berbahasa Arab dan } \\
\text { Inggris sesuai } \\
\text { dengan bakat dan } \\
\text { minat. }\end{array}$ & \\
\hline & $\begin{array}{l}\text { 2. Menyelenggara } \\
\text { kan } \\
\text { pembelajaran } \\
\text { internalisasi } \\
\text { nilai-nilai cinta } \\
\text { ilmu } \\
\text { pengetahuan, } \\
\text { teknologi dan } \\
\text { seni. }\end{array}$ & & $\begin{array}{l}\text { Menghasilkan } \\
\text { lulusan yang } \\
\text { memiliki keluasan } \\
\text { dan kedalaman ilmu } \\
\text { pengetahuan, } \\
\text { terampil dalam } \\
\text { pemanfaatan } \\
\text { teknologi Informasi } \\
\text { serta menyenangi } \\
\text { dan menghargai } \\
\text { seni; }\end{array}$ & \\
\hline & $\begin{array}{l}\text { 3. Menyelenggara } \\
\text { kan } \\
\text { pembelajaran } \\
\text { dalam } \\
\text { mengembangk } \\
\text { an akhlakul } \\
\text { karimah anak } \\
\text { didik }\end{array}$ & 3.1. & $\begin{array}{l}\text { Menghasilkan } \\
\text { lulusan yang } \\
\text { meliliki } \\
\text { pemahaman, } \\
\text { keyakinan, dan } \\
\text { amaliah agama } \\
\text { secara } \\
\text { komprehensif } \\
\text { dalam kehidupan } \\
\text { yang berhaluan }\end{array}$ & \\
\hline
\end{tabular}


JURNAL PIWULANG, Vol. I No. 2 Maret 2019, 137-155

\begin{tabular}{|c|c|}
\hline & $\begin{array}{l}\text { Ahlusunnah Wal } \\
\text { Jama'ah An } \\
\text { Nahdiyah. }\end{array}$ \\
\hline $\begin{array}{l}\text { 4. Menyelenggara } \\
\text { kan } \\
\text { pembelajaran } \\
\text { internalisasi } \\
\text { nilai-nilai cinta } \\
\text { Allah, Sesama } \\
\text { dan Alam } \\
\text { semesta. }\end{array}$ & $\begin{array}{ll}\text { 4.1. } & \text { Menghasilkan } \\
\text { lulusan yang } \\
\text { memiliki karakter } \\
\text { taat kepada Allah \& } \\
\text { Rosul, cinta pada } \\
\text { sesama dan peduli } \\
\text { lingkungan alam } \\
\text { sekitar; }\end{array}$ \\
\hline $\begin{array}{l}\text { 5. Menyelengara } \\
\text { kan } \\
\text { pembelajaran } \\
\text { dalam } \\
\text { mengembangk } \\
\text { an wawasan } \\
\text { nusantara } \\
\text { anak didik }\end{array}$ & $\begin{array}{l}\text { 5.1. Menyiapkan anak } \\
\text { didik yang memiliki } \\
\text { karakter jujur, } \\
\text { disiplin, bersih, } \\
\text { tertib, sopan, dan } \\
\text { bertanggung jawab; }\end{array}$ \\
\hline $\begin{array}{l}\text { 6. } \\
\text { kenyelenggara } \\
\text { pembelajaran } \\
\text { internalisasi } \\
\text { nilai-nilai cinta } \\
\text { diri, bangsa } \\
\text { dan negara }\end{array}$ & $\begin{array}{l}\text { 6.1. Menyiapkan anak } \\
\text { didik yang memiliki } \\
\text { pemahaman } \\
\text { wawasan } \\
\text { nusantara, } \\
\text { kesadaran, } \\
\text { kepedulian, } \\
\text { kecintaan dan } \\
\text { kebanggaan } \\
\text { terhadap diri, } \\
\text { bangsa dan negara; }\end{array}$ \\
\hline & $\begin{array}{l}\text { 6.2. Menghasilkan } \\
\text { lulusan yang siap } \\
\text { berperan aktif di } \\
\text { masyarakat dan } \\
\text { melanjutkan ke } \\
\text { jenjang pendidikan } \\
\text { unggul selanjutnya. }\end{array}$ \\
\hline
\end{tabular}

Tabel 1: Rumusan Visi, Misi, Tujuan serta Program Unggulan Madrasah

b. Analisa Pasar (pengguna jasa pendidikan).

Analisis pasar adalah cara utama untuk mendengarkan pelanggan, dan calon pelanggan. Riset pasar dapat digunakan untuk 
menentukan isu-isu mutu melalui sudut pandang pelanggan. Maka mutu menurut apa yang dirasakan pelanggan harus segera ditetapkan.

Riset pasar bukan sesuatu yang dilaksanakan sekali untuk selamanya, khususnya dalam pendidikan. Institusi pendidikan memiliki fenomena yang menarik menyangkut populasi yang datang dan pergi kemudian digantikan oleh populasi baru. Jika sebuah institusi ingin memenuhi kebutuhan yang diinginkan seluruh pelanggan, maka institusi tersebut harus mengadopsi strategi-strategi berbeda yang disesuaikan dengan segmen pasar yang ada.

c. Analisa SWOT dan faktor penting sukses

1) SWOT adalah singkatan dari Strenghts, Weaknesses, Opportunities and Threats (Kekuatan, Kelemahan, Peluang dan Ancaman). SWOT dapat dibagi ke dalam dua elemen, analisa internal yang berkonsentrasi pada prestasi madrasah itu sendiri, dan analisa eksternal/lingkungan.

Uji kekuatan dan kelemahan pada dasarnya merupakan audit internal tentang seberapa efektif performa institusi. Sementara peluang dan ancaman berkonsentrasi pada konteks eksternal atau lingkungan tempat sebuah institusi beroperasi. Tujuan pengujian ini adalah untuk memaksimalkan kekuatan, meminimalkan kelemahan, mereduksi ancaman dan membangun peluang.

\begin{tabular}{|c|c|}
\hline $\begin{array}{l}\text { Kekuatan } \\
\text { - } \text { Hasil ujian yang baik } \\
\text { - } \text { Moral staf \& siswa yang baik } \\
-\quad \text { Lingkungan berbasis pesantren } \\
\text { - }\end{array}$ & \begin{tabular}{l}
\multicolumn{1}{c}{ Kelemahan } \\
- Bangunan lama dalam kondisi \\
tidak optimal \\
- $\begin{array}{l}\text { Anggaran belanja yang tidak } \\
\text { cukup }\end{array}$
\end{tabular} \\
\hline \begin{tabular}{ll}
\multicolumn{1}{c}{ Peluang } \\
- & Bergairah untuk menata ulang \\
potensi dengan program clonning \\
system. \\
$-\quad$ Peluang untuk mengembangkan \\
keahlian staf untuk \\
meningkatkan daya tawar \\
\end{tabular} & \begin{tabular}{ll} 
& \multicolumn{1}{c}{ Hambatan } \\
- & Resiko kehilangan guru \\
potensial akibat diterima & sebagai ASN \\
$-\quad$ & etos kerja lembaga lain \\
mungkin Menjadi dominan
\end{tabular} \\
\hline
\end{tabular}

Tabel 2: Analisis SWOT Madrasah

2) Faktor penting sebuah kesuksesan, kadangkala disebut peristiwa kunci yaitu indikator-indikator menyangkut hal-hal apa saja yang harus dicapai oleh sebuah madrasah yang ingin memenuhi kepuasan pelanggan dan statemen misinya.

Faktor penting internal bisa meliputi: 1). Bentuk pembelajaran yang memenuhi kebutuhan pelajar misalkan dengan 
project based learning (PjBL) 2). Tim yang berfungsi secara tepat. Sedangkan faktor penting kesuksesan eksternal bisa meliputi: 1). Meningkatnya pasar (animo masyarakat kepada madrasah); dan 2). meningkatnya kepercayaan golongan minoritas atau kelompok yang belum maju.

d. Perencanaan Operasi dan Bisnis.

Perencanaan operasi dan bisnis adalah rencana detail jangka pendek, biasanya satu tahun, untuk mencapai aspek-aspek tertentu dari strategi institusional jangka panjang. Ia mencakup ukuran nyata dan implikasi finansial yang siap diimplementasikan dan non-finansial seperti meningkatnya reputasi, profil dan sebagainya.

e. Kebijakan dan Perencanaan Mutu

Kebijakan mutu adalah sebuah statemen komitmen yang disampaikan madrasah, dan harus mengikuti standar yang digunakan institusi. Jika sebuah institusi menggunakan standar A, maka standar tersebut harus betul-betul diikuti. Selanjutnya, mengembangkan rencanaan mutu yang akan mengantarkan statemen kebijakan mutu pada pelaksanaan mutu. Ia menunjukkan bagaimana proses peningkatan mutu dibuat dan dipertahankan.

f. Biaya Mutu/Kualitas

Biaya mutu adalah biaya yang terjadi atau mungkin akan terjadi karena kualitas buruk. Ini berarti, biaya kualitas adalah biaya yang berhubungan dengan penciptaan, pengidentifikasian, perbaikan dan pencagahan kerusakan. ${ }^{30}$ Biaya untuk mencapai tingkat kualitas tertentu dapat dibagi menjadi biaya yang dapat dihindari dan biaya yang tidak dapat dihindari. Biaya yang dapat dihindari adalah biaya kegagalan produk, meliputi bahan baku yang rusak, jam kerja yang dipergunakan untuk pengerjaan ulang dan perbaikan, pemrosesan keluhan, dan kerugian finansial akibat pelanggan yang kecewa. Biaya yang tidak dapat dihindari dikaitkan dengan inspeksi dan pengendalian kualitas yang dirancang untuk mencegah terjadinya kerusakan. ${ }^{31}$

Cara untuk mengukur biaya mutu dan harus ditekankan, yaitu perbedaan antara biaya pencegahan dengan biaya kegagalan. Biaya pencegahan adalah biaya yang dibutuhkan dalam menghentikan kesalahan dan menjamin bahwa semuanya kembali dilakukan sebagaimana mestinya. Misalnya biaya peningkatan mutu yang mencakup biaya penyusunan sistem mutu, biaya pelatihan dan tim kerja. Biaya ini merupakan biaya lansung dan dapat dihitung jumlahnya. Sedangkan biaya kegagalan lebih sulit diukur, biasanya berbentuk biaya kesempatan, yang diukur melalui hilangnya kesempatan dan bisnis.

30 Nasutioan, Manajemen Mutu ...,Hlm. 127

${ }^{31}$ Nasutioan, Manajemen Mutu ...,, Hlm. 23 
Misalnya ketidakpuasan pelanggan, kurangnya pendaftar, kegagalan para pelajar, dan sebagainya. ${ }^{32}$

g. Pengawasan dan Evaluasi

Proses evaluasi harus fokus pada pelanggan dan mengeksplorasi dua isu, yaitu tingkatan dimana institusi mampu memenuhi kebutuhan individual para pelanggannya, baik internal maupun eksternal. Dan sejauh mana institusi mampu mencapai misi dan tujuan strategisnya. Untuk memastikan bahwa sebuah proses evaluasi mampu mengawasi tujuan individual dan institusional tersebut, maka evaluasi tersebut harus dilakukan dalam 3 level evaluasi:

1) Segera. Melibatkan pemeriksaan harian terhadap kemajuan peserta didik. Tipe evaluasi ini biasanya berlangsung secara informal, dan dilakukan oleh individu-individu guru atau para tingkat tim yang dibentuk oleh madrasah.

2) Jangka pendek. Membutuhkan cara yang lebih terstruktur dan spesifik, yang menjamin bahwa peserta didik sudah berada dalam jalur yang seharusnya dan sedang meraih potensinya. Tujuannya, untuk memastikan perbaikan bagi segala sesuatu yang harus diperbaiki. Penggunaan data statistik dan profil siswa harus ditonjolkan dalam proses ini. Evaluasi ini dilakukan dalam level tim dan lembaga. Penekanannya perbaikan sebagai cara mencegah kegagalan peserta didik.

3) Jangka panjang. Sebuah evaluasi terhadap kemajuan dalam mencapai tujuan strategis. Evaluasi ini merupakan evaluasi yang dipimpin langsung oleh institusi secara keseluruhan. Tipe evaluasi ini dilakukan sebagai sebuah usaha pembuka dalam memperbaharui rencana strategis. Kuesioner bisa digunakan untuk memperoleh umpan balik dari para pelanggan.

\section{A. Kesimpulan}

Adanya perencanaan strategik karna lingkungan dunia yang berubah secara pesat dan tak menentu, suatu organisasi memerlukan kemampuan untuk perubahan perencanaan dan manajemen secara cepat. Maka kemampuan untuk senantiasa melakukan penangkapan lingkungan eksternal dari organisasi, serta upaya terus-menerus untuk senantiasa melakukan penelaahan kemampuan dan kelemahan internal, menjadi prasyarat bagi organisasi untuk tetap strategik dan relevan.

Langkah-langkah dalam penyusunan perencanaan strategi mutu dalam upaya membangun madrasah unggul adalah: 1). merumuskan visi, misi, nilai-nilai, tujuan dan program unggulan dengan pertimbangan tidak keluar dari koridur pendidikan Nasional serta kekhasan madrasah; 2). analisa

32 Sallis, Manajemen Mutu ..., HIm. 232-234 
pasar madrasah dengan mempertimbangkan lokasi, kebutuhan, dan daya dukung; 3). analisa SWOT yang dapat dibagi ke dalam analisa internal yang berkonsentrasi pada prestasi madrasah dan analisa eksternal/lingkungan serta faktor penting sukses yang tertuang dalam statemen visi dan misinya, 4). Perencanaan operasi dan bisnis yang merupakan rencana detail jangka pendek, 5). kebijakan dan perencanaan mutu terkait dengan statemen komitmen yang disampaikan madrasah dalam mengikuti standar tang ditetapkan; 6). Biaya mutu terkait dengan biaya yang berhubungan dengan penciptaan, pengidentifikasian, perbaikan dan pencagahan kerusakan; serta 7. pengawasan dan evaluasi terkait dengan sejauh mana institusi mampu mencapai misi dan tujuan strategisnya.

\section{DAFTAR RUJUKAN}

Akdon. 2006. Strategic Management For Educational Management. Bandung: Alfabeta

Bangun, Wilson. 2008. Intisari Manajemen. Bandung: PT Refika Aditama

David, Fred R. 2006. Manajemen Strategis Edisi 10. Jakarta: Salemba Empat

Gaspersz, Vincent. 2001. Total Quality Management. Jakarta: Gramedia Pustaka Utama

Hardjosoedarmo, Soewarso. 2004. Total Quality Management. Yogyakarta: ANDI

Hubeis, Musa dan Muhamad Najib. 2008. Manajemen Strategik dalam Pengembangan Daya Saing dan Organisasi. Jakarta: PT Elex Media Komputindo

Nasutioan. Manajemen Mutu Terpadu (Total Quality Management). Jakarta: Ghalia Indonesia

Nawawi, Hadari. 2005. Manajemen Strategik Organisasi Non Profit Bidang Pemerintahan. Yogyakarta: Gadjah Mada University Press

Sallis, Edward. 2011. Manajemen Mutu Terpadu Pendidikan. Jogjakarta: Ircisod

Salusu, J. 2006. Pengambilan Keputusan Strategik Untuk Organisasi Publik dan Organisasi Non Profit. Jakarta: Grasindo

Siregar, A. Ridwan. 2008. Manajemen Mutu, pdf

Syaefudin, Udin Sa'ud dan Abin Syamsuddin Makmun. 2007 Perencanaan Pendidikan: Suatu Pendekatan Komprehensif. Bandung: Remaja Rosdakarya 
JURNAL PIWULANG, Vol. I No. 2 Maret 2019, 137-155

Syafaruddin. 2005. Manajemen Lembaga Pendidikan Islam.Jakarta: PT Ciputat Press

Umar, Husein. 2005. Strategic Management in Action. Jakarta: PT Gramedia Pustaka Utama

Wahyudi, Agustinus Sri. 1996. Manajemen Strategik, Pengantar Proses Berpikir Strategik. Binarupa Aksara 